\title{
Digital Citizenship in Croatia: Analysis of Strategic Documents of the National Education Policy and the Citizenship Education Curricula
}

\author{
Ivan Beroš \\ University of Zagreb, Faculty of Teacher Education, Postgraduate student of the Lifelong Learning and \\ Educational Sciences
}

\begin{abstract}
Citizenship education, in Croatian primary and secondary schools realized within the crosscurricular topic, strives to develop students' knowledge and skills, and to encourage the values necessary for taking up the role of an active citizen. In order for citizens to be able to respond to the challenges of modern society, it is necessary to prepare students for the role of digital citizens. Digital citizens understand the importance of technology and its competent usage on impact for everyday life and have the ability to utilize digital technology in a critical and competent manner. Since the aim of education is to prepare students for the challenges of the world, preparing them to be digital citizens should represent one of the pillars of national education policy. The aim of the research presented in this paper was to determine in which sociological context and in what way digital citizenship and digital divide are presented and defined in the curricula of Citizenship Education and strategic documents of the national education policy. Two curricula of Citizenship Education and three strategic documents of the national education policy were analysed by a comparative method and qualitative content analysis. In the analysed documents and curricula, digital citizenship is not mentioned or defined on the conceptual level and on the contextual level it is placed in various sociological frameworks. Analysed documents occasionally point to the strategic importance of Internet access for educational process.
\end{abstract}

Keywords: aims of education; digital democracy; digital citizen; digital divide; policy analysis.

\section{Introduction}

Debates related to citizenship occupy significant spaces within social sciences and in the postmodern turn within social science emphasis is placed on different forms of citizenship. Changes in the debate on citizenship were prompted by the same influences as changes in discussions on most topics within social sciences: the weakening of the national state and the strengthening of globalization, the predominance of individualism over the collectivism, the commodification of almost all aspects of human activity (Ball, 2004; Gilbert, 2008; Giroux, 2011 ; 2014), and the alleged end of history and the dominance of liberal democracy and neoliberalism. In addition to these socioeconomic and political factors changes within the debate on citizenship are stimulated by the transformation of politics, families and social, 
professional and political communities at all levels with continuous interaction (Bronfenbrenner, 1979). Digital technologies were, and still are, the driving force of many described changes. Technology understood as a 'tool' quantitatively and qualitatively transforms our ability to act, and its omnipresence in our everyday life turns it into one of the dominant forms of human interaction with the world. First part of the paper presents the theoretical development of democracy caused by the evolution of information and communication technologies (ICT) through the developmental path from teledemocracy to digital citizenship, and then analyses digital citizenship focusing on different approaches to digital citizenship in EU and Anglosphere. After analysis of the origin and implications of digital citizenship, the role of digital divide for the practical implementation of digital citizenship is considered. The second part of the paper presents methodology and results of research that sought to determine in which way and in what sociological context digital citizenship and digital divide are present in strategic documents of Croatian education policy and initial and final curricula of Citizenship Education in Croatia.

\subsection{Development of digital democracy: from teledemocracy to digital citizenship}

Due to the ubiquitous presence of television in everyday life of individuals from the developed world since the 1980s the importance of television as a medium on political life became evident (especially in the United States), and thus consideration of the political importance of television, known as teledemocracy, began. The emergence of teledemocracy was considered a positive trend as the opinion prevailed that television could contribute to informing citizenship and bringing politics closer to the public (Dutton, 1992; Kinder, 2002). In the era of teledemocracy, television has become the main factor influencing the possibility of correctly judging the content of the candidate's political agenda and its implications for the everyday life of an individual by less informed voters (Rahn \& Cramer, 1996).

Entry of the Internet into households lead to a weakening of television influence on the political socialisation of citizens, especially political socialisation of young people that are from birth surrounded by computers and the Internet. With its architecture and networking possibilities, the Internet has provided a way and hope for a revolutionary transformation of the process of political socialisation and communication. The Internet's main promise was to "reduce the distance between the ruling elite and the citizens ... by lowering the price of communication between citizens and the government" (Hale et al., 2005, p. 107), which was not achieved in practice (Herman \& Chomsky, 2010; McChesney, 2013) since politicians remained the dominant senders of preformed messages. The predominance of the Internet over television and other digital media has led to the identification of digital citizenship with the transfer of different practices constituting citizenship (Ishin \& Nielsen, 2008) to Internet (Ishin \& Ruppert, 2015). Within the digital citizenship discourse there are differences depending on the stakeholders that design the discourse.

\subsection{The European Union policy of digital citizenship}

The European Union (EU) is a politico-economical community of European States created in order to facilitate business operations and the flow of goods and people within Europe. From its very beginning it was clear that a community based solely on economic integration could not be maintained and education was singled out as a particularly important area for the further development of the European Union and European integration (Rifkin, 2006; Spajić-Vrkaš, 2007). A digital citizenship policy has emerged as a logical consequence of these two political 
processes. As the EU encourages migration within its borders, common EU policies seek to foster a sense of digital cohesion (Ponzaneni \& Leurs, 2014) with the country of residence and home country. To further encourage the connectivity of EU resident efforts on development of common European citizenship have been launched, resulting in certain rights for all citizens of EU (Delanty, 2007). The citizenship of the Union is conceived as complementary to the citizenship of the national state and not as its substitute (Bellamy, 2008) and in order for the Union citizenship to satisfy the needs of European citizens, and respond to the challenges of life in the information society (Hafner Fink \& Oblak Črnič, 2014) marked by networking, EU has developed a policy of the digital citizenship.

EU policy of digital citizenship relies on digital competence which "involves the safe, critical and responsible use of digital technologies for the purposes of learning, working and participation in society" (European Union, 2019, p. 10). The overall goal of digital competence has been operationalized through five areas: information, communication, content creation, security and problem solving (Ferrari, 2013). The EU policy of digital citizenship signifies active and responsible participation in the global, national and local communities on the political, economic, social, cultural and intercultural fields of activity with a competent and positive attitude towards digital technologies (Frau-Meigs et al., 2017, p. 15). Furthermore, EU policy of digital citizenship points to the importance of digital technologies that enable creation, sharing, retrieval and use of information and digital content in a critical, collaborative and creative way (Carretero et al., 2017) through various digital and online platforms.

\subsection{The global conception of digital citizenship}

E-Democracy (Qvortrup, 2013) and digital democracy (Wilhelm, 2000; Hindman, 2009) have emerged as predecessors of digital citizenship. In practice, the above mentioned conceptualization of democracy would not be possible without ICT, so it's plausible to view the developmental path from teledemocracy to digital citizenship as a developmental route of technology from newspapers (McLuhan, 1963) to television, and then to smartphone and Internet (Hague \& Loader, 1999). The global conception of digital citizenship refers to the approach to the digital citizenship dominant in the Anglosphere, and is presented separately from the European policy of digital citizenship as there is one paradigmatic difference. While the EU policy of digital citizenship underlines the importance of digital technology, digital media and internet for digital citizenship, the global conception of digital citizenship almost exclusively emphasizes the theoretical and practical impact of the Internet on the social and political status of citizenship (Hague \& Loader, 1999; Mossberger et al., 2007).

The theoretical discourse of the global conception does not unequivocally define what is and what digital citizenship includes which is evident from the multitude of existing definitions of digital citizenship. Mossberger and associates (2007, p. 1) define digital citizenship as "the ability to participate in society online" and the ability to act politically and economically in the information society (Mosssberger et al., 2007, p. 140). In the other place, Mossberger (2008, p. 173) defines digital citizenship as the possibility and ability of everyday internet access.

Bailey and Ribble (2007, p. 10) describe digital citizenship as "a standard of appropriate and responsible behaviour when using technology." Authors conceptualize digital citizenship through nine digital elements: access, trading, communication, literacy, etiquette, laws, rights and responsibilities, health and well-being, and safety. Furthermore, the authors point out that digital citizenship is a way to respond to the challenges facing users of technology. Bailey and Ribble (2007) deprive digital citizenship of its political aspect and turn it into a response to 
technological challenges that is not a task of digital citizenship, but rather falls within the domain of computer literacy.

For Lenhart and associates (2011, p. 25) digital citizenship represents "what teenagers experience on social networks." This definition further reduces the scope of digital citizenship from political socialization and online action to political socialization and actions solely on social networks. From the Lenhart's and associates (2011) description of the digital citizenship it is ambiguous how social networks can satisfactorily fill the content of the term digital, and in particular it is ambiguous how social networks can represent the scope of the term citizenship (Petrović, 2015), which is defined by politologist in various ways, emphasizing different psychological, sociological and political starting theories (Haste, 2004).

What can be concluded about the global conception of digital citizenship from several presented and analysed definitions? On the one hand there is the concept of digital citizenship as a provider of public administration services via the Internet, and on the other hand there are authors who conceptualize digital citizenship as solutions to the problems of modern democracy, without paying attention to the transformation of citizenship in modern societies. However, there is one element that is present in discussions of almost all authors engaged in the digital citizenship scholarship regardless of whether they adhere to a European policy or global conception, and whether they approach digital citizenship as a form of digitalization of government services or conceptualize digital citizenship within emancipation potential.

\subsection{Digital divide: an obstacle to digital political participation?}

The importance of digital divide for converting theoretical possibilities of digital citizenship into practice is analysed using Pippa Norris (2001) definition. The author defines the digital divide as a multi-dimensional term consisting of three divides. Differences in the Internet access between developed and developing countries make up a global divide, the gap between information rich and information poor States represents a social divide, and the democratic divide points to differences between those who use and those who do not use the range of "digital resources for mobilization, engagement and participation in public life" (Norris, 2001, p. 17). Research of digital divide have established one regularity: the existing socioeconomic inequalities are replicated through digital divide which affects possibility for using digital technology and the Internet. Therefore, the existing economic and political relations of power within a particular society and between States (Hague \& Loader, 1999; Norris, 2001; Papacharissi, 2008; Hindman, 2009; Vromen, 2017), are becoming even more pronounced (Norris, 2000). The digital divide points to the systemic nature of differences in the ability to access digital technology and the Internet by lines of income, education, and gender. The differences in ability to use computers and the Internet should be added to these differences as they affect opportunities for practicing digital citizenship whose development is also conditioned by mentioned factors (Zukin et al., 2006; Mossbeger et al., 2007).

\section{Research methodology}

\subsection{Research questions}

1. In what context and how is digital citizenship presented through the initial and final phase of the formation of the first formal curriculum of the cross-curricular topic Citizenship education in Croatia?

2. In what context and how is digital citizenship presented in strategic documents that represent the framework for education policy in Croatia? 
3. To which extent is the influence of the digital divide on equal opportunities for education, professional progress and personal development of individuals elaborated in the curricula of Citizenship education (CE) and strategic documents of the national educational policy?

\subsection{Method}

The research was conducted using deductive qualitative content analysis (Elo \& Kyngäs, 2008) and comparative method on the citizenship education curricula, as well as strategic documents that represent the framework for education policy in Croatia. Individual strategic documents and curricula from the sample were selected as the unit of analysis. In the first step research categories and topics were "selected, based on the research questions and the conceptual model" (Groenland, 2018, p. 123). EU policy and global approach to digital citizenship provided base topics and categories for data collection (Graneheim et al., 2017). Categories representing "descriptive level of text" (Vaismoradi et al., 2016, p. 102), were derived from documents through analysis (Hsieh \& Shannon, 2005) and their development was based on questions presented research sought to answer. In development of the categories Constas (1992) documentational approach for category development was used (tab. 1). In the second step selected curricula and strategic documents of the national education policy were analysed in relation to selected categories (Hsieh \& Shannon, 2005). After anlysing the documents from the sample using encoding grid (Rössler, 2012), a comparison of documents was made at the contextual and conceptual level (Esser \& Vliegenthart, 2017), with regard to selected categories. The similarities and differences between documents were analysed at conceptual level (Mills et al., 2006) with respect to categories of concept and definitions of digital citizenship, and the presentation and analysis of digital divide. On the contextual level the sociological context within which the dominant discourse of analysed strategic documents of education policy is situated was analysed.

Table 1: Details of the categorization process following Constas (1992) and Vaismoradi et al. (2016)

\begin{tabular}{|c|l|}
\hline Component & Description \\
\hline Origination & $\begin{array}{c}\text { Investigator as point of origination. Researcher referred to research and published } \\
\text { works in the relevant area and derived categories congruent with research } \\
\text { questions. }\end{array}$ \\
\hline Verification & $\begin{array}{c}\text { Referential strategy. Existing research findings and theoretical arguments were } \\
\text { used to justify the use of particular categories. }\end{array}$ \\
\hline Nomination & Category names were derived from existing theories and body of literature \\
\hline
\end{tabular}

\subsubsection{Coding procedure}

Figure 1."illustrates the codebook used to guide the development of the theme [and] fostering relationships" (Creswell \& Poth, 2017, p. 191) in coding process for theme "Digital citizenship" which was used for analysis of selected document of education policy and CE curricula. Each category has been assigned with code in a way that one code corresponded to one category (Fig. 1). Coding was performed manually by paper and pencil technique (Saldana, 2012) because research sample was relatively small (Basit, 2003). In presented research coding process was a bit different than usual qualitative coding (Hahn, 2008; Saldana, 2012). Level 2 coding resulted in four codes (APPROACH, TFRAM, SOCTH, DD) and Level 3 coding provided two codes (CONCEPTL, CONTEXTL). These six codes were used to filter content (Saldana, 2012) from analysed document into theoretically predefined categories. Relations and interactions between codes and categories are shown in Figure 2. In most textbooks authors follow the 
coding path from initial to focus and axial coding which result in development of theoretical concept (Milas, 2005; Cohen, 2007; Hahn, 2008: Saldana, 2012, Creswell \& Poth, 2017). In presented research theme and categories was defined from the beginning. The aim of research is located within level 3 coding in conceptual and contextual level of analysis of selected documents of educational policy and CE curricula. Presented research sought to analyze representation of categories on conceptual and contextual level in selected document, and therefore above mentioned changes in coding procedure were made.

Figure 1: Coding procedure for theme digital citizenship in Croatia

Theme

Level 3 coding

Level 2 coding

Category

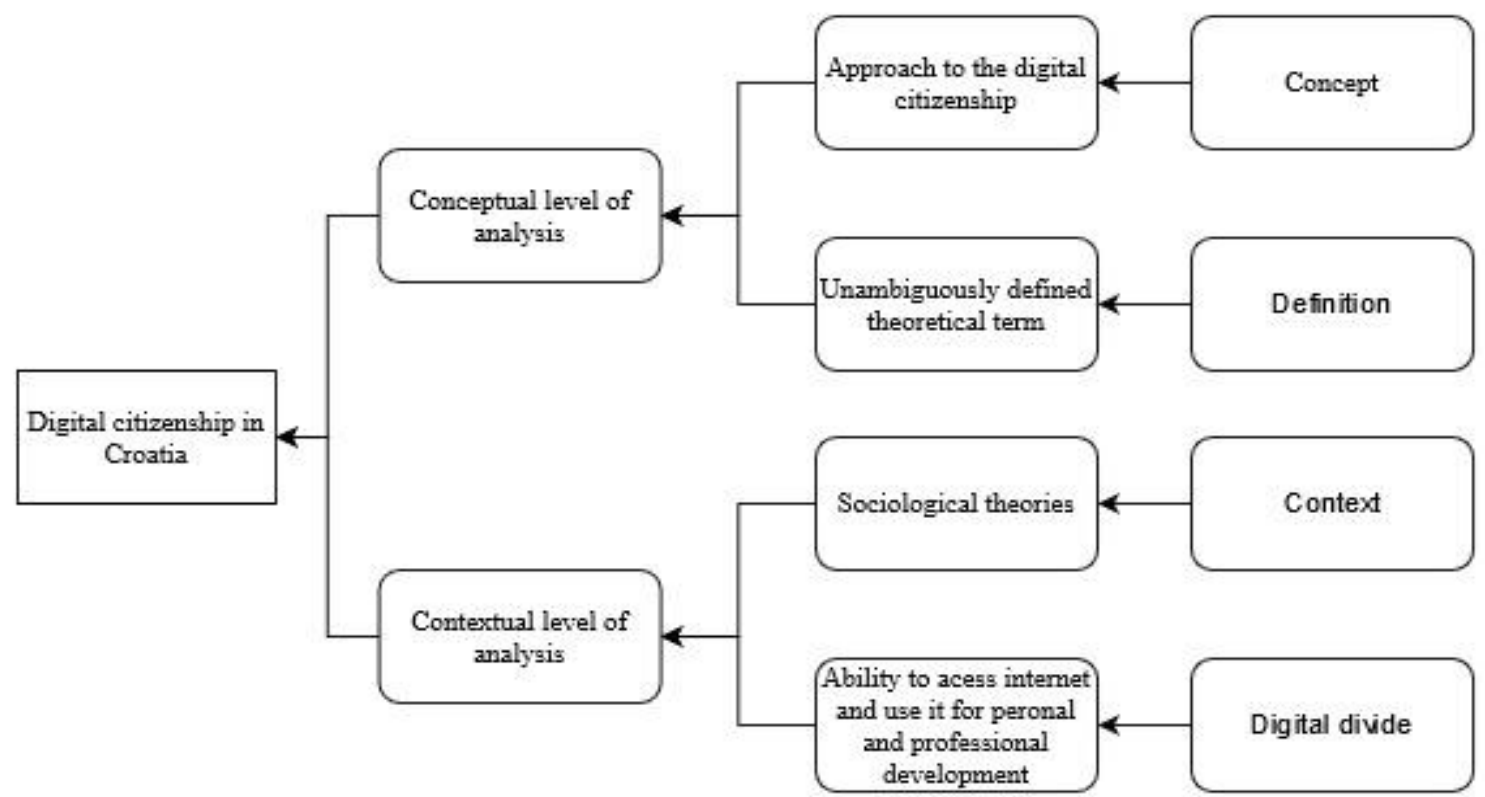

Figure 2: Relations between codes and categories for theme digital citizenship in Croatia

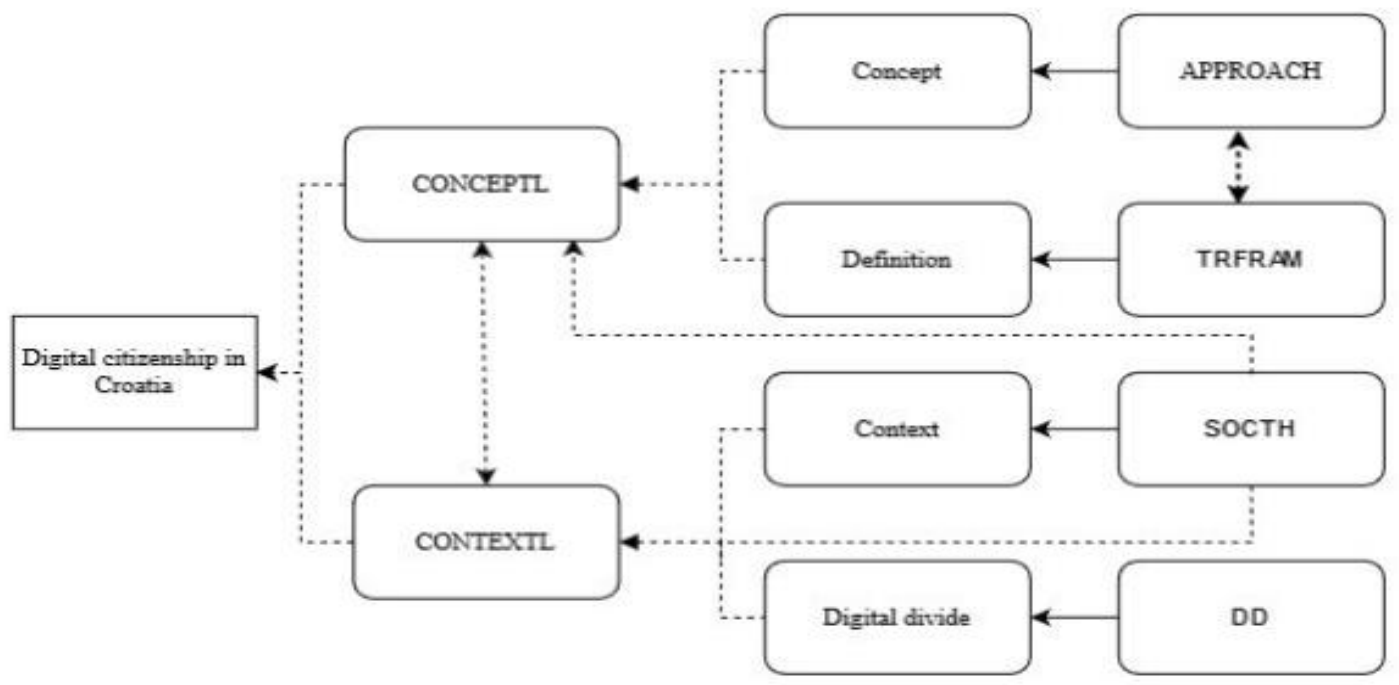

\subsection{Sample}


For research purposes two samples of documents were formed, appropriately called the curriculum sample and the strategic documents sample. The sample of curriculum consists of two curricula of citizenship education: Curriculum for the Cross-curricular Topic Citizenship Education for Elementary and High schools in the Republic of Croatia from 2019 published by the Ministry of Science and Education (NN 10/2019) and Citizenship education curriculum from 2012 published by the Agency for Education (AZOO, 2012). Two curricula created between the initial and final curricula of the $\mathrm{CE}$ are excluded from the analysis since the curricula of the CE from 2016 and 2017 represent working proposals of the curriculum which ultimately resulted in the latest official curriculum of the CE in 2019 published by the Ministry of Science and Education. Aim of presented research was to analyze the present approach to digital citizenship and not its development through all phases of CE curriculum development. Curricula included in the sample of analysed curricula gained support in academia and were implemented in schools representing framework of Citizenship education in Croatia, and therefore were analysed.

The sample of strategic documents consists of three strategic documents: the National Curriculum for Primary Education [NC] (MZO, 2017), Strategy for Education, Science and Technology [Strategy] (NN 124/2014) and the National Curriculum Framework for Preschool and Compulsory Primary and Secondary Education [NCF] (MZOŠ, 2010). These three document form sample of strategic documents because their interactions form a backbone of educational policy in Croatia. NCF is created as all-encompassing framework of compulsory level of education in Croatia. Strategy has a global approach taking into account bedrocks of modern society: education, science and technology. In part of Strategy related to education strong ties to a NCF are stressed. NC is result of Comprehensive Curricular Reform (Beroš \& Pongračić, 2018) and that position give this policy document leading position in shaping education in Croatia on system-wide policy level.

\subsection{Instrument}

For the purpose of the research a descriptive document analysis matrix (Bates Averill, 2002) consisting of "terms arranged in rows and columns ... within which something takes form" (Agnes, 2000, p. 887) was constructed. As a framework of matrix analysis relevant categories steaming from research questions were selected (Elo et al., 2014). The following categories were selected as relevant: the presentation of the context of digital citizenship, the presentation of the concept of digital citizenship, the definition of digital citizenship and the presentation and analysis of the digital divide. Extracted categories were placed along the top horizontal row of this matrix. The context of digital citizenship refers to the predominantly sociological theories used for positioning educational discourse. The concept of digital citizenship signifies approach to digital citizenship which points its origins, the objective(s) in its basis and the method of realization, and the segment of the population at which the approach is aiming. The definition of digital citizenship is an unambiguously defined theoretical term that enables reliable and valid theoretical use of the term (Cohen et al., 2007; Milas, 2005). The digital divide is defined as the ability to access the Internet and the ability to use the Internet for the purpose of finding information, education, professional progress and personal development. Analysed documents were placed along the left vertical border of the matrix (Bates Averill, 2002)

\subsection{Results}




\subsubsection{Digital citizenship in strategic documents}

National Curriculum Framework for Preschool and Compulsory Primary and Secondary Education [NCF] (MZOŠ, 2010) is dominated by the context of globalization at sociological level (Giddens, 2005), which is demonstrated by the orientation of the educational system towards "the development of a society based on knowledge and globalization process" (MZOŠ, 2010, p. 11). At the same time, the focus within educational policy is on development of key competences for lifelong learning, relying on the European Reference Framework of Key Competences for Lifelong Learning (EC, 2010; AZOO, 2012, p. 4) with the aim of creating a knowledge society (MZOŠ, 2010, p. 11). In line with the discourse of the knowledge society (Bindé, 2005), NCF stresses the importance of technology for the everyday life of students in and outside the school. However, the effects of technology in general and in particular digital divide on students' ability to participate in the political, social and economic life of society are not analysed within the NCF. The objectives of the NCF cross-curricular topics Information and Communication Technology and Citizenship education do not include familiarization of students with the effects of technology on reproduction of existing socio-political and economic power relationships (Hague \& Loader, 1999; Norris, 2001; Papacharissi, 2008; Hindman, 2009; Giroux, 2011; 2014; Vromen, 2017), and the negative consequences of non-ability to access technology and the Internet to equal opportunities for education, professional progress and personal development of individuals.

In the Strategy (NN 124/2014) the context of the discussion arises from EU documents which "connect research and innovation and elaborate a triangle of knowledge between education, research and innovation" (NN 124/2014, p. 213). No mention is made of democracy or citizenship in the context described above, although the topics of democratic and European citizenship are the basis for strengthening European integration (Pauwels \& Burgelman, 2003; Spajić-Vrkaš, 2007). The concept of digital citizenship is not present in the Strategy at all and is therefore not defined. Digital citizenship is not present in the Strategy even when the possibilities provided by ICT and the Internet for the ubiquitous activities of individuals are discussed. The discussion on the Internet access highlights its strategic importance (NN $124 / 2014$, p. 120) for the success of individuals in the fields of education, employment and personal development.

The National Curriculum (MZO, 2017) sets lifelong learning as the basis for active and responsible participation in society. In the National Curriculum [NC] lifelong learning is seen as a means to develop fundamental values: knowledge, entrepreneurship, identity, respect, responsibility, solidarity, integrity and health (MZO, 2017, p. 5-6) among students. As it can be seen, according to the NC democracy is not one of the fundamental values that educational system should develop among students. Digital citizenship is not explicitly represented in the $\mathrm{NC}$, but several elements of digital citizenship are mentioned within the field of information and digital literacy (MZO, 2017, p. 10). NC states that "proper use of technology is one of the preconditions for effective participation and decision-making in the digital age" (MZO, 2017, p. 67) indicating the relevance of digital citizenship, although digital citizenship is not present on the conceptual level in NC or within the cross-curricular topic Citizenship education. Analysis of the importance of technology should emphasize both the positive (as is the case) and negative consequences of digital divide, but these are not mentioned in NC. Results of analysis of strategic documents of the national educational policy are shown in Figure 3. Numbers 1, 2 and 3 are standing for analysed documents in following order: 1. National Curriculum Framework for Preschool and Compulsory Primary and Secondary Education 
2nd International Academic Conference on Education, Teaching \& Learning

[NCF] (MZOŠ, 2010); 2. National Curriculum for Primary Education [NC] (MZO, 2017); 3. Strategy for Education, Science and Technology [Strategy] (NN 124/2014)

Figure 3: Analysis of strategic documents of the national education policy for theme digital citizenship in Croatia

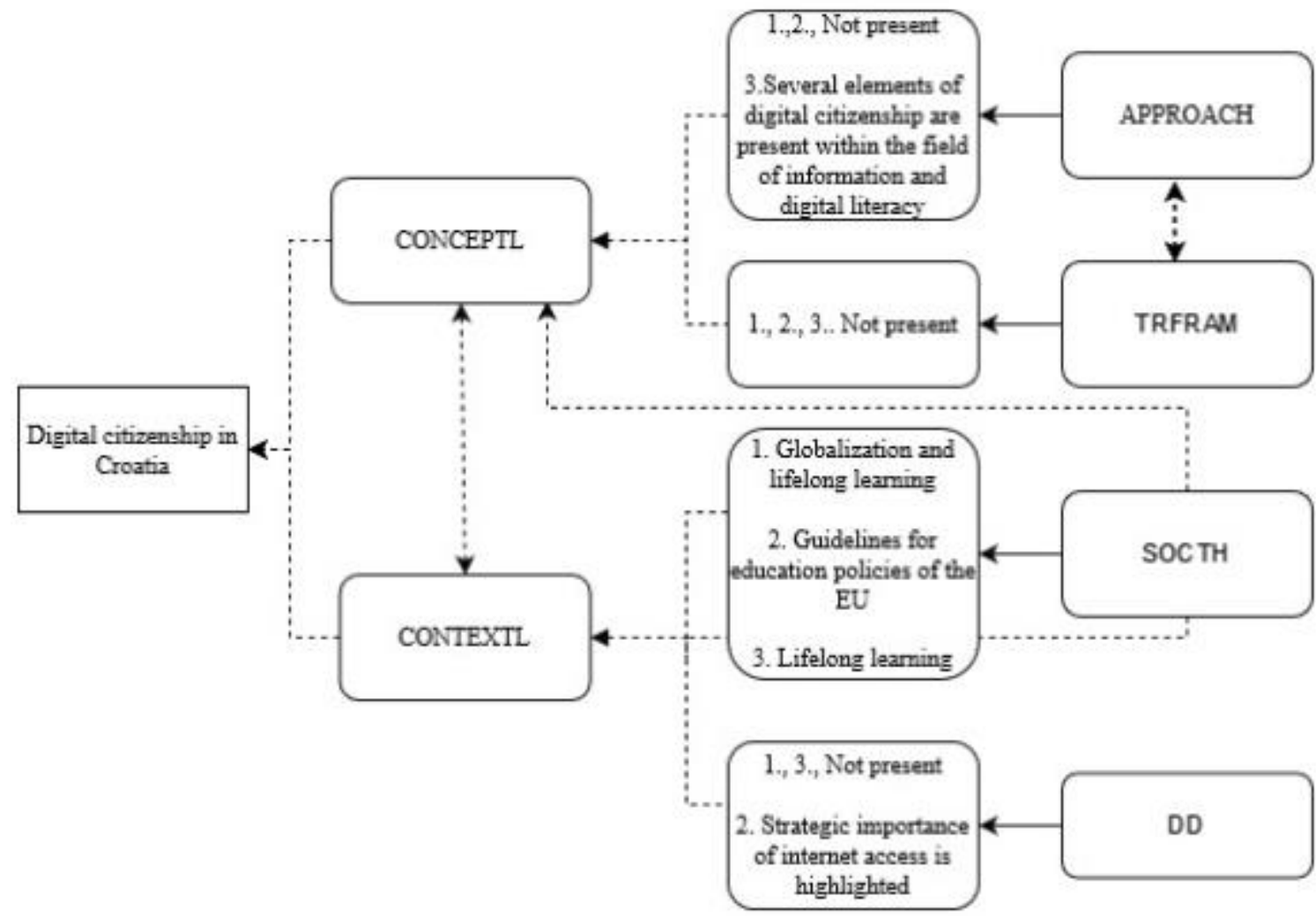

\subsubsection{Digital citizenship in the Citizenship education curricula}

The Citizenship education curriculum from 2012 takes on a competency-based approach for the context framework (AZOO, 2012, p. 3) to planning and programming the educational system, which is in agreement with the discourse of the knowledge society designated as a broader framework within which the CE curriculum is positioned (AZOO, 2012, p. 4). Other categories of analysis matrix (concept, definition of digital citizenship and the analysis of digital divide) are not represented in the CE curriculum from 2012. Newest curriculum of the CE in Croatia (NN, 2019) cites a pluralistic society and a competency-based approach to planning and programming of the educational system as the context of its educational efforts. Within the CE curriculum from 2019, neither the concept nor definition of digital citizenship is present nor there is mention or analysis of the impact of the digital divide on the everyday possibilities of students (Fig. 4). Numbers 4 are 5 standing for analysed documents in following order: 4. Citizenship Education Curriculum (AZOO, 2012); 5. Curriculum for the Cross-curricular topic Citizenship Education (NN, 2019). 
Figure 4: Analysis of Citizenship education curriculum for theme digital citizenship in Croatia

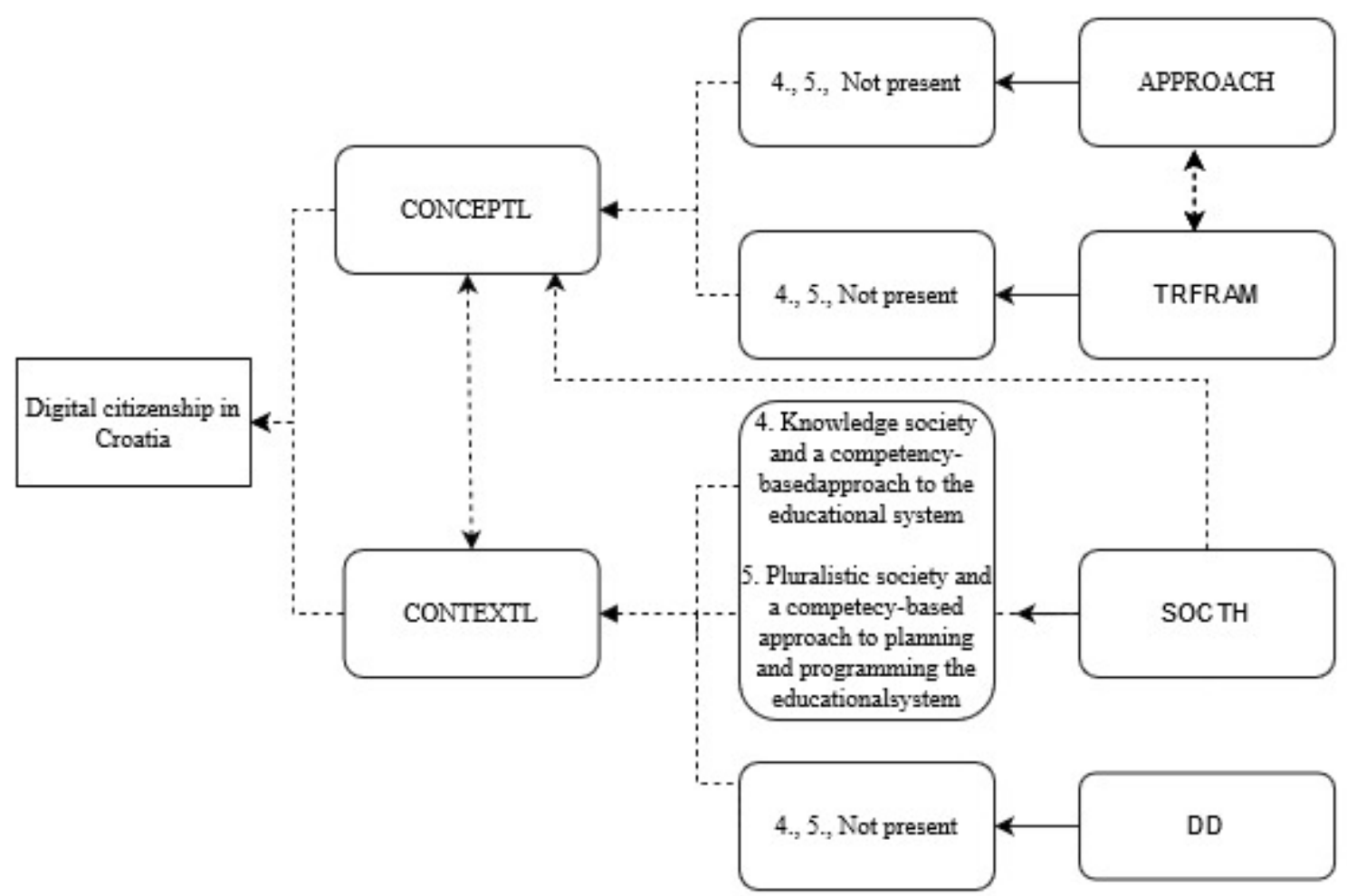

Given the results of analysis of strategic documents of the national education policy and $\mathrm{CE}$ curricula the research presented in this paper resulted by the following conclusions:

1. In the analysed documents digital citizenship is not mentioned at conceptual level, i.e. the analysed curricula of $\mathrm{CE}$ and strategic documents do not show the origins and objectives of digital citizenship, nor the methods for its practical realization.

2. On the contextual level, digital citizenship is placed within various sociological theoretical frameworks.

3. Digital citizenship is not defined in the analysed CE curricula.

4. Through the initial and final phase of formation of the first formal curriculum of crosscurricular topic Citizenship education, the content of the curriculum does not indicate to the presence of digital divide among the citizens of Croatia, and its negative consequences for equal opportunities for education, professional progress and personal development of the individual. Analysis of the impact of technology in general, especially the consequences of the possibility of Internet access for self-determination of individuals, are completely missing from the analysed CE curricula.

5. The strategic documents of national education policy that represent the framework for primary and secondary education in Croatia do not define digital citizenship.

6. The Strategy for Education, Science and Technology underlines the strategic importance of access to the Internet on the national level for educational purposes.

\subsection{Discussion}

Digital citizenship is a part of the Citizenship education and within this context the results obtained in the research presented in this paper are analysed. Earlier analysis of the curricula of 
CE (Beroš \& Pongračić, 2019) came up with results that show Croatian educational policy declarative commitment to $\mathrm{CE}$, which has almost no relevance for educational practice. In the case of digital citizenship, the situation is much worse since the concept of digital citizenship is present in only one (National Curriculum for Primary Education, MZO, 2017) out of five analysed documents. The absence of the concept of digital citizenship from the analysed curricula of the $\mathrm{CE}$ and strategic documents of the national education policy indicates that there is no interest in the subject of digital citizenship at the level of the educational policy.

Educational policy's lack of interest is accompanied by the lack of interest of the academic community. The exploratory search of the Catalog of the National University Library, the portal of Croatian scientific and professional journals Hrčak and the National repository of undergraduate and graduate thesis ZIR, with regard to the title and keywords 'digital citizenship' on 8th May 2020 resulted in one article on digital citizenship. Search through online search engine Google with the keyword 'digital citizenship' without limiting the time period resulted in four relevant sources among the first fifty results (Školski portal, 2016; Naranđa, 2017; GONG, 2018; Udruga IKS, 2018), and Google Scholar search with same parameters resulted in three relevant sources among the first fifty results (Puzek \& Krolo, 2014; Šagi, 2015; Luatti, 2017). These results further strengthen the conclusion that there is practically no interest in digital citizenship in Croatia.

The absence of interest in digital citizenship has practical implications. In 2019, $81 \%$ of households in Croatia had access to the Internet (Državni zavod za statistiku, DZS 2019), and therefore the basic precondition for digital citizenship is fulfilled by most citizens. However, the question is how many Internet users of the school age have developed the capacity to practice digital citizenship? The results of the international research on information and computer literacy have shown that every fourth school student in Croatia operates at the first level or below the first level of information and computer literacy (National Centre for External Evaluation of Education, NCVVO 2013) which means that students does not "possess basic skills in using computers as a source of information" (NCVVO, 2013, p. 3). If students do not possess the basic skills necessary to use computers and the Internet as a source of information, they cannot even try to become digital citizens.

Since a concept of digital citizenship is absent from analysed documents that represent a framework for educational policy, results of analysis of dominant sociological context are pointing to a conclusion that within Croatian educational policy network society (Castells, 1996) and globalization represent dominant sociological theories on which approach to digital citizenship is based. These two theories share many common features and represent the backbone for both global and EU policy of digital citizenship, that stress the importance of individuals' connectivity on national and international level. Theories of globalization and network society are dominant sociological theories used for sociological analysis, both in Europe and on the global scale. Therefore, the analysis presented in this paper point to the identical sociological context surrounding the global conception and EU policy of digital citizenship. As a result of dominant sociological theories within which it originates, digital citizenship as it is conceptualized in two presented approaches is mostly oriented at global issues and/or is searching for regional and global solution for issues nurturing multi-stakeholder approach. From the data presented in this paper, it isn't possible to conclude which of two analysed conceptions of digital citizenship is dominant on the level of national education policy in Croatia. But since most efforts within national educational policy steam from recommendations and initiatives of EU for the educational system of member states (Cankaya 
et al., 2015) it is plausible to conclude that EU policy of digital citizenship represent a framework for the conceptualization of education for digital citizenship at national level.

In Croatia we have the following situation modelled by data presented in this paper: individuals of the school age mostly have access to the Internet, but each fourth is functionally illiterate in information and computer sense. This should be added to the fact that in Croatia the Internet in 2018 was more expensive and less accessible in rural areas than the European average (Knezović, 2019). Furthermore, educational policy at the national level further affects the already poor outlook for digital citizenship by completely excluding digital citizenship from the CE curricula thus revoking its status of 'legitimate knowledge' (Apple, 2006; 2012). Although educational policy states that the Croatian educational system prepares students for future challenges, the analysis presented in this paper shows that the definition of future challenges of the Croatian Ministry of Education and Science does not include individuals engaged in traditional civic practices (Ishin \& Nielsen, 2008; Beroš \& Pongračić, 2019) nor digital citizenship practices.

The argument that Citizenship education (Findak, 2019), and consequently digital citizenship as its integral part, is an important aspect of national education policy is unsustainable since digital citizenship is not represented in strategic documents of education policy and $\mathrm{CE}$ curricula. The results of the research presented in this paper show that neither the strategic documents of the educational policy nor the $\mathrm{CE}$ curricula define digital citizenship, which shows that digital citizenship is not discussed at the educational policy level. After rejecting the thesis of the educational policy on the importance of the CE (Beroš \& Pongračić, 2019) and digital citizenship for a quality and modern educational system, we are faced with the question of motivation for such action by the national educational policy?

Educational systems can take on various orientations: conservative, liberal and transformative (Apple, 2006; 2012) related to the dominant social values (Petričusić et al., 2017; Beroš \& Pongračić, 2018). An analysis of the category of CE curricula referring to the vision of students pointed to the dominant understanding of students by educational policy as individuals active in local community (Beroš \& Pongračić, 2019). Emphasizing the activity of students the CE curriculum from 2019 made a shift from conservative to liberal and transformative value orientation. The question is, what is the nature of student activity and does it stimulate the development of a liberal value system? The activities of the students listed in the CE curriculum from 2019 are aimed at political socialization in order to maintain the stability of the political system and society as a whole. Within the CE curriculum from 2019 students' political participation is construed as knowledge of certain political developments at national and international level, individual action driven by interest in certain political and social issues and participation in elections (NN, 2019; Ekman \& Amnå, 2012). The above mentioned activities corresponds with the dominant values that influenced the process of educational reform in Croatia (Beroš \& Pongračić, 2018), which resulted in the CE curriculum from 2019.

Activism and protest, as a legitimate forms of direct political and civic participation (Verba $e t$ al., 1995; Norris, 2002; Zukin et al., 2006; Ekman \& Amnå, 2012), are not present in the categories of knowledge, attitudes and values that CE curiculum from 2019 strives to develop in students. The absence of these legitimate forms of direct civic participation in democratic societies confirms the conservative orientation of the CE curriculum, and the Ministry of Science and Education. Since digital citizenship provides significant opportunities for political and social activism (Verba et al., 1995; Norris, 2002; Papacharissi, 2010; Giroux, 2011; Howard \& Hussain, 2013) and for the exercise of direct democracy (especially for the group of citizens between fifteen and thirty years), it is not difficult to understand, taking into account 
the results of the analysis of the dominant values and views of students within the $\mathrm{CE}$ curriculum (Beroš \& Pongračić, 2019), why digital citizenship is not present in analysed CE curicula and strategic documents of national education policy.

\section{Conclusion}

Under the influence of social, political, economic and cultural factors (Stevenson, 2003; Miller, 2007; Beaman, 2016) changes have occurred in the design of citizenship related to its content and scope. Technological development is one of the significant influences, and the emergence and rise in the importance of television has led to the theory of teledemocracy, the dominance of the Internet between different means of communication and digital media among the mediators of reality has prompted discussions on digital citizenship. Since there is not much research on digital citizenship in Croatia, the research presented in this paper was aimed at determining within which sociological context and theoretical conceptualization digital citizenship is presented in the initial and final phase of formation of the first formal curriculum of cross-curricular theme Citizenship education and in strategic documents of the national education policy. The research also tried to answer the question about the extent to which and in which ways the strategic documents of education policy and the CE curricula present and analyze the importance of digital divide for equal opportunities for education, professional progress and personal development of individuals. Research results should be considered critically since the analysis matrix is designed for the purpose of the research presented in this paper and the results obtained refer only to selected categories, which does not mean that there are no other relevant aspects of digital citizenship whose presence within the analysed curricula is not taken into account in the presented research.

Research results show that digital citizenship is not mentioned or defined on the conceptual level in the strategic documents of education policy and in the curricula of the CE, and at the contextual level digital citizenship is placed within various sociological theoretical frameworks. Results of the research also confirm that there is no indication of the presence of digital divide among Croatian citizens within the curriculum of the $\mathrm{CE}$ and the strategic documents of education policy. Obtained results can help to explain the relationship between national educational policy and the CE, since digital citizenship is its integral part. The content of the analysed CE curricula indicates that digital citizenship does not occupy an important position within Croatian educational policy because it encourages active citizenship and underlines the importance of activism and political activity of young people, which are not values encouraged within the Croatian educational system and society in general.

The research results also show that digital citizenship is neglected by educational policy and academia, which has implications for the education of future generations for the practice of democracy. If we want future generations to be competent citizens of modern democratic society changes at national and local level are needed. CE should in practice become an integral part not only of the school curriculum, but of the students lived experience in school, and the everyday life of students is the reason why it is necessary to act towards the development of the theory and practice of digital citizenship in Croatia at all levels. Whether we admit it or not, students have developed digital identities that represent integral parts of their global identity, and it is therefore necessary that educational system prepare them for a competent action guided by democratic principles within digital spaces. 


\section{References}

Agencija za odgoj i obrazovanje [AZOO] (2012). Kurikulum Građanskog odgoja obrazovanja [Citizenship education curriculum] Retrieved from https://www.azoo.hr/images/Kurikulum_gradanskog_odgoja_i_obrazovanja.pdf [6. 5. 2020.] Agnes, M. (Ed.). (2000). Webster's New World College Dictionary, 4th ed. Foster City, CA: IDG Books Worldwide.

Alwin, D. F. and McCammon, R. J. (2003). Generations, cohorts, and social change. In J. T. Mortimer and M. J. Shanahan (Eds.), Handbook of the life course (pp. 23-49). New York, NY: Kluwer Academic Publishers.

Ansolabehere, S., Snowberg, E. C. and Snyder, J. M. Jr. (2006). "Television and the incumbency advantage in US elections, "Legislative Studies Quarterly, vol. 31, no. 4, pp. 469490. doi: https://doi.org/10.3162/036298006X201896

Apple, M. W. (2006). Educating the "Right" Way: Markets, Standards, God, and Inequality, 1 st ed. New York and London: Routledge.

Apple, M. W. (2012). Ideologija i kurikulum [Ideology and Curriculum], 1st ed. Beograd, Serbia: Fabrika knjiga.

Assarroudi, A., Heshmati, N., Fatemeh, A., Mohammad, R., Ebadi, A. and Vaismoradi, M. (2018). "Directed qualitative content analysis: the description and elaboration of its underpinning methods and data analysis process," Journal of Research in Nursing, vol. 23, no. 1, pp. 42-55. doi: https://doi.org/10.1177/1744987117741667

Averill, J. B. (2002). "Matrix analysis as a complementary analytic strategy in qualitative inquiry," Qualitative Health Research, vol. 12, no.6, pp. 855-866.

Bailey, G. and Ribble, M. (2007). Digital Citizenship in Schools, 1st ed. Eugene, OR: International Society for Technology in Education.

Ball, S. J. (2004). "Education for sale! The commodification of everything?,“ King's annual education lecture, London, UK: Institute of Education, University of London and Mimeo.

Basit, T. (2003). "Manual or electronic? The role of coding in qualitative data analysis," Educational research, vol. 45, no. 2, pp. 143-154.

Beaman, J. (2016). "Citizenship as cultural: Towards a theory of cultural citizenship," Sociology Compass, vol. 10, no. 10, pp. 849-857. doi: https://doi.org/10.1111/soc4.12415

Bellamy, R. (2008). "Evaluating Union citizenship: Belonging, rights and participation within the EU,“ Citizenship Studies, vol. 12, no. 6, pp. 597-611. doi: https://doi.org/10.1080/13621020802450676

Beroš, I. (2018). "Kreativnost kao transcendentalno-aktivistička karakteristika pojedinca," [Creativity as transcedental-activist characteristic of the individual] Acta Iadertina, vol. 15, no. 2, pp. 49-72. doi: https://doi.org/10.15291/ai.2813

Beroš, I. and Pongračić, L. (2018). "The impact of the 'Conservative modernization' on the educational system in Croatia: The conceptual and implementational pressures in the process of Comprehensive curricural redorm, “" Metodički obzori, vol. 13, no. 1 (25), pp. 77-100. doi: https://doi.org/10.32728/mo.13.1.2018.04

Beroš, I. and Pongračić, L. (2019, October). “Analiza razvoja (kurikuluma) Građanskog odgoja i obrazovanja u hrvatskoj perspektivi" [Citizenship education curriculum development analysis from the Croatian perspective], In Zbornik radova s konferencije Suvremene teme u odgoju $i$ obrazovanju - STOO, simpozij Pedagogija i psihologija: od ispravljanja nedostataka do poticanja osobnih snaga i vrlina.Zagreb, Croatia, pp. 7-30, Sveučilište u Zagrebu, Učiteljski fakultet. 
Bindé, J. (2005). Towards Knowledge Societies: UNESCO World Report, 1st ed. Paris, France: UNESCO.

Bronfenbrenner, U. (1979). The Ecology of Human Development: Experiments by Nature and Design, 1st ed. New York and London, NY and UK: Harvard University Press.

Cankaya, S., Önder K. and Cebeci, E. (2015). "The educational policy of European Union," Procedia: Social and Behavioral Sciences, vol. 174, pp. 886-893. doi: https://doi.org/10.1016/j.sbspro.2015.01.706

Carretero, S., Vuorikari, R., and Punie, Y. (2017). The Digital Competence Framework for Citizens 1st ed. Luksemburg: Publications Office of the European Union.

Castells, M. (1996). The information age, Vol. 1: The rise of the network society 1st ed. Cambridge \& Oxford, MA \& UK: Blackwell.

Cohen, L., Manion, L. and Morrison, K. (2007). Metode istraživanja u obrazovanju [Research Methods in Education] 1st ed. Jastrebarsko, Croatia: Naklada Slap.

Creswell, J. W. and Poth, C. N. (2017). Qualitative Inquiry and Research Design: Choosing Among Five Approaches $4^{\text {th }}$ ed. Thousand Oaks, CA: Sage.

Delanty, G. (2007). "European citizenship: A critical assessment,“ Citizenship Studies, vol. 11, no. 1, pp. 63-72. doi: https://dx.doi.org/10.1080/13621020601099872

Dutton, W. H. (1992). "Political science research on teledemocracy," Social Science Computer Review, vol. 10, no. 4, pp. 505-522. doi: https://doi.org/10.1177/089443939201000405

Ekman, J. and Amnå, E. (2012). "Political participation and civic engagement: Towards a new typology, "Human Affairs, vol. 22, no. 3, pp. 283-300. doi: https://doi.org/10.2478/s13374-0120024-1

Elo, S. and Kynga, S. H. (2008). "The qualitative content analysis process,“ Journal of Advanced Nursing, vol. 62, no.1, pp. 107-115. doi: https://doi.org/10.1111/j.13652648.2007.04569.x

Elo, S., Kääriäinen, M., Kanste, O., Pölkki, T., Utriainen, K. and Kyngäs, H. (2014). "Qualitative content analysis: A focus on trustworthiness," SAGE Open, vol. 4, no. 1. doi: https://doi.org/10.1177/2158244014522633

Esser, F. and Vliegenthart, R. (2017). "Comparative research methods." In J. Matthes, C. S.and R. F. Potter (Eds.), The international encyclopedia of communication research methods (pp. 122). Hoboken, N.J.: John Wiley \& Sons.

European Commision [EC] (2010). "Preporuka Europskog parlamenta i savjeta: Ključne kompetencije za cjeloživotno učenje - europski referentni okvir [Council recommendationon key competences for lifelong learning],“ Metodika, vol. 11, no. 20, pp. 169-182. https://hrcak.srce.hr/61536

European Union [EU] (2019). Key Competences for Lifelong Learning. Luksemburg: Publications Office of the European Union.

Ferrari, A. (2013). DIGCOMP. A Framework for Developing and Understanding Digital Competence in Europe, 1st ed. Sevilla, Spain: Joint Research Centre of the European Commission.

Findak, S. (2019). "Građanski odgoj od jeseni u svim školama“" [Citizenship education from autumn in every school]. vijesti.hrt.hr. Retrieved from https://vijesti.hrt.hr/486710/graanskiodgoj-od-jeseni-u-svim-skolama [13. 5. 2020.]

Frau-Meigs, D., O’Neill, B., Soriani, A. and Tomé, V. (2017). Digital Citizenship Education, Volume 1: Overview and new perspectives, 1st ed. Strabourg, France: Council of Europe.

Giddens, A. (2005). Odbjegli svijet: Kako globalizacija oblikuje naše živote [Runaway World: How Globalization is Reshaping our Lives], 1st ed., Zagreb, Croatia: Jesenski i Turk. 
Gilbert, J. (2008). "Against the commodification of everything: Anti-consumerist cultural studies in the age of ecological crisis, “ Cultural Studies, vol. 22, no. 5, pp. 551-566. doi: https://doi.org/10.1080/09502380802245811

Giroux, H. A. (2011). On Critical Pedagogy, 1st ed. New York, NY: Continuum.

Giroux, H. A. (2014). Neoliberalism's War on Higher Education, 1st ed. Chicago, IL: Haymarket Books.

GONG. (2018). E-participacija i digitalna demokracija: Od lokalne zajednice do razine EU [E-participation and Digital Democracy: From Local Community to EU]. Retrieved from https://edu.gong.hr/wp-content/uploads/2019/09/ISBN_BRO\%C5\%A0URA_E-participacijai-digitalna-demokracija_lokEU.pdf [13. 5. 2020.]

Graneheim, U. H., Lindgren, B. M. and Lundman, B. (2017). "Methodological challenges in qualitative content analysis: A discussion paper," Nurse Education Today, vol. 56, pp. 29-34. doi: https://doi.org/10.1016/j.nedt.2017.06.002

Groenland, E. (2018). "Employing the matrix method as a tool for the analysis of qualitative research data in the business domain, "Int. J. Business and Globalisation, vol. 21, no. 1, pp.119134. doi: https://doi.org/10.2139/ssrn.2495330

Hafner Fink, M. and Oblak Črnič, T. (2014). "Digital citizenship as multiple political participation? Predictors of digital political participation in Slovenia," Teorija in Praksa, vol. 51, no. 6, pp. 1284-1303.

Hague, B. N. and Loader, B. D (2005). "Digital democracy. An introduction." In: B. N. Hague and B. D. Loader (Eds.), Digital Democracy: Discourse and Decision Making in the Information Age (pp. 3-22). London and New York, UK and NY: Routledge.

Hale, M., Musso, J. and Weare, C. (2005). "Developing digital democracy: Evidence from Californian municipal web pages." In: B. N. Hague and B. D. Loader (Eds.), Digital Democracy: Discourse and Decision Making in the Information Age (pp. 111-130). London and New York, UK and NY: Routledge.

Haste, H. (2004). "Constructing the citizen," Political Psychology, vol. 25, no. 3. pp. 413-439. doi: https://doi.org/10.1111/j.1467-9221.2004.00378.x

Herman, E. S and Chomsky, N. (2002). Manufacturing Consent: The Political Economy of the Mass Media, 2nd ed. New York, NY: Random House.

Hindman, M. (2008). The Myth of Digital Democracy. Princeton, NJ: Princeton University Press.

Hoskins, B., Villalba, E., Van Nijlen, D. and Barber, C. (2008). Measuring Civic Competence in Europe. 1st ed. Ispra, Italy: European Commission, Joint Research Centre, Institute for the Protection and Security of the Citizen and Centre for Research on Lifelong Learning (CRELL) retrieved from https://core.ac.uk/download/pdf/38618456.pdf [13. 5. 2020.]

Hoskins, B., Villalba, C. M. H. and Saisana, M. (2012). The 2011 Civic Competence Composite Indicator (CCCI-2): Measuring Young People's Civic Competence Across Europe Based on the IEA International Citizenship and Civic Education Study, 1st ed. Ispra, Italy: European Commission, Joint Research Centre, Institute for the Protection and Security of the Citizen and Centre for Research on Lifelong Learning (CRELL).

Hoskins, B., Saisana, M. and Villalba, C. M. H. (2015). "Civic competence of youth in Europe: Measuring cross national variation through the creation of a composite indicator," Social Indicators Research, vol. 123, no. 2, pp. 431 - 457. doi: https://doi.org/10.1007/s11205-0140746-Z

Howard, P. N. and Hussain, M. M. (2013). Democracy's Fourth Wave? Digital Media and the Arab Spring, 1st ed. New York, NY: Oxford University Press. 
Hsieh, H-F and Shannon, S. E. (2005). "Three approaches to qualitative content analysis," Qualitative Health Research, vol. 15, no. 9, pp. 1277-1288. doi: https://doi.org/10.1177/1049732305276687

Ishin, E. F. and Nielsen, G. M. (2008). "Introduction." In E. F. Ishin and G. M. Nielsen (Eds.), Acts of Citizenship (pp. 1-12). London and New York, UK and NY: Zed Books.

Engin, I. F. and Ruppert, E. (2015). Being Digital Citizens, 1st ed. London and New York, UK and NY: Rowman and Littlefield.

Kaid, L. L. and Dimitrova, D. V. (2005). "The television advertising battleground in the 2004 presidential election,“ Journalism Studies, vol. 6, no. 2, pp. 165-175. doi: https://doi.org/10.1080/14616700500057205

Kinder, T. (2002). "Vote early, vote often? Tele-democracy in European cities," Public Administration, vol. 80, no. 3, pp. 557-582. doi: https://doi.org/10.1111/1467-9299.00318

Knezović, G. (2019, November). "Hrvatska ima jedan od najskupljih interneta u EU" [Croatia has one of the most expensive Internet in the EU], mreza.bug.hr. Retrieved from https://mreza.bug.hr/hrvatska-ima-jedan-od-najskupljih-interneta-u-eu/ [13. 5. 2020.]

Krolo, K. and Puzek, I. (2014) "Upotreba internetskih društvenih mreža i participacijske dimenzije društvenoga kapitala mladih na primjeru Facebooka [Usage of Internet social networks and participatory dimensions of social capital of youth - The example of Facebook]", Društvena istraživanja: časopis za opća društvena pitanja, 23(3), str. 383-405. doi: https://doi.org/10.5559/di.23.3.01

Luatti, L. (Ed.) (2017). Ljudska prava u doba digitalnog građanstva: III. susret ljudskih prava [Human Rights in the Era of Digital Citizenship]. Italija, Francuska and Hrvatska: Regija Toskana, Sveučilište u Firenci, Oxfam Italia, Regija Normandija, Međunarodni institut za mir i ljudska prava u Caenu and Istraska županija.

McChesney, R. W. (2013). Digital Disconnect: How Capitalism is Turning the Internet Against Democracy, 1st ed. New York: The New Press

McGillivray, D. G., McPherson, G., Jennifer, J. and McCandlish, A. (2016). "Young people, digital media making and critical digital citizenship," Leisure Studies, vol. 35, no. 6, pp. 724738. doi: https://doi.org/10.1080/02614367.2015.1062041

McLeod, R. J. (1999). "The sociodrama of presidential politics: Rhetoric, ritual, and power in the era of teledemocracy,“American Anthropologist, vol. 101, no.2, pp. 359-373.

McLuhan, M. (1963). The Gutenberg Galaxy: The Making of Typographic Man, 2nd ed. Toronto, ON: University of Toronto Press.

Milas, G. (2005). Metode istraživanja u psihologiji i drugim društvenim znanostima, 1st ed. [Research Methods in Psychology and Other Social Sciences], Jastrebarsko, Croatia: Naklada Slap.

Miller, T. (2007). Cultural Citizenship: Cosmopolitanism, Consumerism, and Television in a Neoliberal Age, 1st ed. Philadelphia, PA: Temple University Press.

Mills, M., Van de Bunt, G. G. and De Bruijn, J. (2006). "Comparative research: Persistent problems and promising solutions," International Sociology, vol. 21, no. 5, pp. 619-631. doi: https://doi.org/10.1177/0268580906067833

Ministarstvo znanosti i obrazovanja [MZO] (2017). Nacionalni kurikulum za osnovnoškolski odgoj i obrazovanje - prijedlog nakon javne rasprave [National Curriculum for Primary Education - draft after public discusion]. Zagreb, Croatia: Ministarstvo znanosti i obrazovanja. Ministarstvo znanosti, obrazovanja i športa [MZOŠ] (2010). Nacionalni okvirni kurikulum za predškolski odgoj i obrazovanje te opće obvezno i srednjoškolsko obrazovanje. [National 
Framework Curriculum for Preschool and Compulsory Primary and Secondary Education] Zagreb, Croatia: Ministarstvo znanosti, obrazovanja i športa.

Mossberger, K. (2008). "Toward digital citizenship: Addressing inequality in the information age." In A. Chadwick and P. N. Howard (Eds.), Routledge Handbook of Internet Politics (pp. 189-201). London and New York, UK and NY: Routledge.

Nacionalni centar za vanjsko vrednovanje obrazovanja NCVVO] (2013). ICILS 2013: međunarodno istraživanje računalne i informacijske pismenosti [ICILS 2013: International Computer and Information Literacy Study]. Zagreb, Croatia: Nacionalni centar za vanjsko vrednovanje obrazovanja.

Naranđa, I. (2017, June). "OŠ PRIBISLAVEC eTwinning projekt 'Digital Citizenship'« [Primary school Pribislavec eTwinning project 'Digital Citizenship']", emedimurje.net.hr. Retrieved from https://emedjimurje.net.hr/vijesti/skolski-kutak/3025083/etwinning-projektdigital-citizenship/ [13. 5. 2020.]

Narodne novine [NN] (2014). Strategija obrazovanja, znanosti i tehnologije [Strategy of Education, Science and Technology], 124/2014 [13. 5. 2020.]

Narodne novine [NN] (2019). Odluka o donošenju kurikuluma za međupredmetnu temu Građanski odgoj i obrazovanje za osnovne i srednje škole u Republici Hrvatskoj [Decision on the adoption of the Curriculum for the Cross-curricular Citizenship Education for primary and secondary schools in the Republic of Croatia] [10/2019] [13. 5. 2020.]

Norris, P. (2000). A Virtuous Circle: Political Communications in Postindustrial Societies, 1st ed. Cambridge, UK: Cambridge University Press.

Norris, P. (2001). Digital Divide. Civic Engagement, Information Poverty, and the Internet Worldwide, 1st ed. Cambridge, UK: Cambridge university press.

Norris, P. (2002). Democratic Phoenix: Reinventing Political Activism, 1st ed. Cambridge, UK: Cambridge University Press.

Papacharissi, Z. (2008). "The virtual sphere 2.0: The Internet, the public sphere, and beyond." In: A. Chadwick and P. Howard (Eds.), Routledge Handbook of Internet Politics (pp. 246-261). London and New York, UK and NY: Routledge.

Papacharissi, Z. (2010). A Private Sphere: Democracy in a Digital Age, 1st ed. Cambridge and Malden, UK and MA: Polity Press.

Pauwels, C. and Burgelman, J-C. (2003). "Policy challenges to the creation of a European Information Society: A critical analysis." In: J. Servaes (Ed.), The European Information Society: A Reality Check (pp. 59-85). Bristol and Portland, UK and OR: Intellect Books.

Petričušić, A., Mateja Č. and Čepo, D. (2017). "Gaining political power by utilizing opportunity structures: An analysis of the conservative religious-political movement in Croatia“, Politička Misao, vol. 54, no. 4., pp. 61-84. https://hrcak.srce.hr/190338

Petrović, G. (2015). Logika, [Logic], 1st ed. Zagreb, Croatia: Element.

Ponzanesi, S. and Leurs, K. (2014). "On digital crossings in Europe," Crossings: Journal of Migration \& Culture, vol. 5, no. 1, pp. 3-22. doi: https://doi.org/10.1386/cjmc.5.1.3_1

Rahn, W. M. and Cramer, K. J. (1996). "Activation and application of political party stereotypes: The role of television," Political Communication, vol. 13, no. 2, pp. 195-212. doi: https://doi.org/10.1080/10584609.1996.9963107

Rifkin, J. (2006). Europski san, [The European Dream], 1st ed. Zagreb, Croatia: Školska knjiga. Rogić-Hadžalić, D., Brković, L. and Markuš, H. (Eds) (2019). "Primjena informacijskokomunikacijskih tehnologija (IKT) u kućanstvima i kod pojedinaca u 2019., prvi rezultati““ [Usage of information and communication technologies (ICT) in hauseholds and by individuals, 2019, first results], u: Priopćenje LVI.(2.3.2.), Zagreb, Croatia: Državni zavod za 
statistiku. Retrieved from https://www.dzs.hr/Hrv_Eng/publication/2019/02-0302_01_2019.htm [13.5.2020.]

Rössler, P. (2012). "Comparative content analysis.“'In: F. Esser and T. Hanitzsch (Eds.), The Handbook of Comparative Communication Research (pp. 481-490). New York and Abingdon, NY and UK: Routledge.

Saldana, J. (2013). The Coding Manual for Qualitative Researchers $2^{\text {nd }}$ ed. London, UK: Sage. Spajić-Vrkaš, V. (2007). "Europske integracije i obrazovanje za demokratsko građanstvo u cjeloživotnoj perspektivi [European integration and education for democratic citizenship in lifelong perspective].“ In: V. Previšić, N N. Šoljan and N. Hrvatić (Eds.), Pedagogija prema cjeloživotnom obrazovanju $i$ društvu znanja (pp. 380-394), [Pedagogy Toward Lifelong Education and Knowledge Society] vol. 1. Zagreb, Croatia: Hrvatsko pedagogijsko društvo. Stevenson, N. (2003). "Cultural citizenship in the 'cultural'society: A cosmopolitan approach," Citizenship Studies, vol. 7, no. 3, pp. 331-348. doi: https://doi.org/10.1080/1362102032000098904

Šagi, F. (2015). Digitalna demokracija: praksa, mogućnosti i rizici, neobjavljeni diplomski rad [Digital democracy: practice, posibilities and risks, unpublished master's thesis]. Filozofski fakultet u Zagrebu, Odsjek za sociologiju. Retrieved from http://darhiv.ffzg.unizg.hr/id/eprint/6146 [13. 5. 2020.]

Školski portal (2016). "Digitalno građanstvo u žarištu" [Digital citizenship in focus] Retrieved from https://www.skolskiportal.hr/clanak/3555-digitalno-gradanstvo-u-zaristu/ [13. 5. 2020.] Udruga IKS (2018). "iDebate u Srednjoj školi H. Kostajnica“ [iDebate in highschool H. Kostajnica] Retrieved from http://udrugaiks.hr/idebate-u-srednjoj-skoli-h-kostajnica/ [13. 5. 2020.]

Verba, S., Schlozman, K. L. and Brady, H. E. (1995). Voice and Equality: Civic Voluntarism in American Politics, 1st ed. Cambridge, MA: Harvard University Press.

Vromen, A. (2017). Digital Citizenship and Political Engagement: The Challenge from Online Campaigning and Advocacy Organisations, 1st ed. London, UK: Palgrave Macmillan.

Zukin, C., Keeter, S., Andolina, M., Jenkins, K. and Carpini, M. X. D. (2006). A New Engagement? Political Participation, Civic Life, and the Changing American Citizen, 1st ed. New York, NY: Oxford University Press.

Qvortrup, M. (2013). The Politics of Participation: From Athens to E-democracy, 1st ed. Manchester, UK: Manchester University Press.

Wilhelm, A. G. (2000). Democracy in the Digital Age: Challenges to Political Life in Cyberspace, 1st ed. London, UK: Psychology Press. 